\title{
The Battle between Virus and Host: Modulation of Toll-Like Receptor Signaling Pathways by Virus Infection
}

\author{
Shin-ichi Yokota, Tamaki Okabayashi, and Nobuhiro Fujii \\ Department of Microbiology, Sapporo Medical University School of Medicine, South-1, West-17, Chuo-ku, Sapporo 060-8556, Japan \\ Correspondence should be addressed to Nobuhiro Fujii, fujii@sapmed.ac.jp
}

Received 29 November 2009; Accepted 7 April 2010

Academic Editor: Martha Triantafilou

Copyright ( $) 2010$ Shin-ichi Yokota et al. This is an open access article distributed under the Creative Commons Attribution License, which permits unrestricted use, distribution, and reproduction in any medium, provided the original work is properly cited.

In order to establish an infection, viruses need to either suppress or escape from host immune defense systems. Recent immunological research has focused on innate immunity as the first line of host defense, especially pattern recognition molecules such as Toll-like receptors (TLRs), RIG-I-like receptors (RLRs), and NOD-like receptors (NLRs). Various microbial components are recognized by their vague and common molecular shapes so-called, pathogen-associated molecular patterns (PAMPs). PAMPs induce inflammatory reactions mediated by the activation of the transcription factor, NF- $\kappa \mathrm{B}$, and by interferons, which lead to an antiviral immune response. Viruses have the capacity to suppress or escape from this pattern recognition molecule-mediated antimicrobial response in various ways. In this paper, we review the various strategies used by viruses to modulate the pattern recognition molecule-mediated innate immune response.

\section{Introduction}

The host immune system recognizes and eliminates invading pathogenic microorganisms such as viruses, bacteria, and fungi. The first line of defense in mammals is the innate immune system. Recently, the mechanisms by which the innate immune system recognizes pathogen have been extensively studied. Pattern recognition molecules/pathogen recognition receptors (PRRs) are classified into three families: Toll-like receptors (TLRs), RIG-I-like receptors (RLRs), and nucleotide binding-oligomerization domain (NOD)-like receptors (NLRs) $[1,2]$. Ten TLRs (TLR1 to 10) have been identified in humans. The RLR family contains retinoic acid-inducible gene I (RIG-I) and melanoma differentiation associated gene 5 (MDA5) [3]. The NLR receptor family contains NOD1, NOD2, NLRP3, NLRPC5, NLRP1, NAIP, and CIITA [4]. In addition, DNA-dependent activator of interferon regulatory factors (DAI) has been identified as a DNA sensor [5]. Various microbial components are recognized as their vague and common molecular shapes by PRRs. Early responses against virus infection are initiated on recognition of pathogen-associated molecular patterns (PAMPs) by pattern recognition molecules, triggering two responses. One is the production of interferons (IFNs) resulting in an antiviral state as part of the innate immune response, and the second is maturation of dendritic cells (DCs) to establish acquired immunity. In order to establish an infection within a host, viruses must escape from and/or suppress the immune system by various strategies. An important strategy used by viruses is modulation of PAMPinduced immune responses.

TLR signaling proceeds via two pathways: the myeloid differentiation factor 88 (MyD88)-mediated pathway, and the Toll-interleukin-1 receptor (TIR)-domain-containing adaptor inducing IFN- $\beta$ (TRIF)-mediated pathway $[1,2]$. The former causes activation of the transcription factor NF$\kappa \mathrm{B}$, which activates various genes contributing inflammatory reactions. The latter causes induction of IFNs, whose stimulation leads cells to antiviral state. TLR3 only activates the TRIF-mediated pathway. TLR3 signaling activates IRF3 , an important transcription factor for IFN- $\beta$, and IFN production is induced. TLR2 only activates the MyD88mediated pathway. However, TLR4 activates both pathways, so TLR4 agonists activate NF- $\kappa$ B and induce IFN production. Cytosolic PRRs, such as RIG-I, MDA5, and DAI, commonly activate IRF-3. The expression of PRRs differs depending on 
the cell type. Importantly, it is different between cells derived from myeloid stem cells (myeloid dendritic cells (mDCs), monocytes, macrophages, Langerhans cells, and neutrophils) and cells derived from lymphatic stem cells (plasmacytoid dendritic cells (pDCs), T cells, and B cells). For example, TLR7 and TLR9 are rarely expressed on mDCs, whereas TLR3 and TLR8 are rarely expressed on pDCs. TLR4, on the other hand, is expressed at very low levels on both pDCs and mDCs.

\section{Viruses and Innate Immunity}

Initially, viruses invade the host epithelial tissues found in the oral cavity, respiratory tract, intestinal tract, and the urogenital apparatus (Figure 1). Lamina propria DCs, Langerhans cells, and stromal cells are resident in these tissues. In the connective tissues, fibroblasts resident, and capillary vessel and lymphatic vessel are expanded. Monocytes, macrophages, $\mathrm{T}$ cells, $\mathrm{B}$ cells, $\mathrm{pDC}$, and $\mathrm{mDC}$ circulate within the blood vessels and lymphatic vessels, and patrol the interstitial spaces. All these cells are potential targets for virus infection. Virus-infected epithelial cells and fibroblasts produce IFNs, mainly IFN- $\beta$ and IFN- $\lambda$, which provide surrounding uninfected cells with antiviral state. Furthermore, chemokines and cytokines, such as interleukin- $1 \beta$ (IL$1 \beta)$, IL-6, IL-8, granulocyte-macrophage colony-stimulating factor (GM-CSF), and tumor necrosis factor- $\alpha$ (TNF- $\alpha$ ) are also produced. These molecules promote chemotaxis of the resident DCs (lamina propria DCs and Langerhans cells) toward virus-infected and dead cells. Neutrophils, monocytes, macrophages, plasma cells, mDCs, and pDCs also migrate from the blood vessels to the site of infection. IFN- $\gamma$ inducible protein 10 (IP-10), monocyte chemotactic protein 1 (MCP-1), macrophage inflammatory protein-2 (MIP-2), MIP- $3 \alpha$, and MIP- $3 \beta$ largely contribute to the transmigration of blood DCs. However, these blood-borne immune cells can also be infected by viruses, which can then modulate the production of various cytokines and chemokines.

To establish an infection, viruses need to suppress a number of host immune responses, the antiviral activity induced by IFNs, the chemotaxis of immune cells induced by chemokines/cytokines, the maturation and activation of DCs, activation of NK and NKT cells, transmigration of mature DCs to the lymph nodes, and the differentiation and activation of $\mathrm{T}$ cells and $\mathrm{B}$ cells in the lymph nodes, for example. When viruses infect immune cells, such as DCs, the infected cells frequently show suppression of maturation and differentiation, suppression of cytokine receptor and costimulatory molecule expression, secretion of molecules that mimic cytokines and cytokine receptors, and so on. Furthermore, infected cells often alter their cytokine profiles. These strategies are used by the virus to inhibit the acquired immune response. In addition, it has been suggested that virus infection induces regulatory $\mathrm{T}$ cells.

\section{RNA Virus}

3.1. Human T Lymphotropic Virus Type 1 (HTLV-1). HTLV1 , which is a retrovirus, infects $\mathrm{CD}^{+}{ }^{+} \mathrm{T}$ lymphocytes, $\mathrm{CD}^{+}$
T lymphocytes, DCs, B cells, macrophages, and astrocytes, and preferentially replicates in $\mathrm{CD} 4^{+} \mathrm{T}$ lymphocytes. HTLV1 causes latent infection as a provirus, whose genome is integrated into the host DNA, and does not replicate in cells in G0 phase. When the infected T lymphocytes are stimulated with antigen presentation from DCs, they proliferate triggering HTLV-1 replication. During the replication stage, a viral protein, Tax, activates NF- $\kappa \mathrm{B}$ and promotes the growth of infected cells via upregulation of IL-2 and IL-2 receptors $[6,7]$. NF- $\kappa \mathrm{B}$ also activates the long terminal repeat (LTR) of HTLV-1 genome, which further enhances viral replication [8]. The replicated virus induces a host immune response, and cells infected with virus are eliminated by the induction of cytotoxic T cells specific for HTLV-1 Tax. In patients with HTLV-1-associated myelopathy/tropical spastic paraparesis (HAM/TSP), the high proviral load induces a strong HTLV-1-specific immune response [9]. This leads to the rapid elimination of infected cells through the induction of proinflammatory cytokines and cytotoxic $\mathrm{T}$ lymphocytes. So, in order to escape from acquired immune responses, HTLV-1 needs minimum replication and latent infection.

Some virus proteins are known as negative regulators of replication. The HTLV-1 basic leucine-zipper factor (HBZ) protein suppresses Tax-mediated transcription activation of the viral LTR [10]. The $\mathrm{p} 30$ protein suppresses transcription of mRNAs encoding Tax and Rev [11]. p30 also contributes to the expression of TLR2, TLR4, and TLR9, and activation of IRF4. In monocytes, the TLR2 gene promoter is regulated by the transcription factors Sp1, Sp3, and PU.1 [12], and the TLR4 gene by ISRE and PU.1 [13]. p30 downregulates the expression of both TLR2 and TLR4, because it binds to PU.1 and prevents it from binding to DNA [14]. This leads to the suppression of DC maturation, and of their subsequent migration to the lymph nodes. Furthermore, p30 suppresses the enzymatic activity of glycogen synthetase kinase $3 \beta$ (GSK3 $\beta$ ) through promotion of the phosphorylation of nine serine residues. This leads to the induction of IL-10, which suppresses the function of macrophages, and also the maturation and activation of DCs. In fact, serum IL10 levels are elevated in patients with adult $\mathrm{T}$ lymphocyte leukemia. These immunosuppressive properties of IL-10 indirectly contribute to the inhibition of virus replication and to the suppression of virus-induced immune responses. Activation of infected T lymphocytes by DCs in the lymph nodes and cell-to-cell transmission of virus are considered to be important for virus proliferation in human. The viral p12 protein suppresses cell surface expression of both MHC class I and the IL-2 receptor, and also suppresses linker for activation of $\mathrm{T}$ cells (LAT), which is an adaptor protein required for $\mathrm{T}$ cell activation [15]. This results in suppression of $\mathrm{T}$ cells and dystunction of the stimulation/activation by DCs via the T cell receptor. HTLV-1 causes proliferation of infected cells rather than virus and suppression of host immune responses, which helps it to maintain a latent infection in order to survive.

3.2. Human Immunodeficiency Virus (HIV). HIV is another retrovirus that uses similar escape strategies to HTLV-1. HIV 


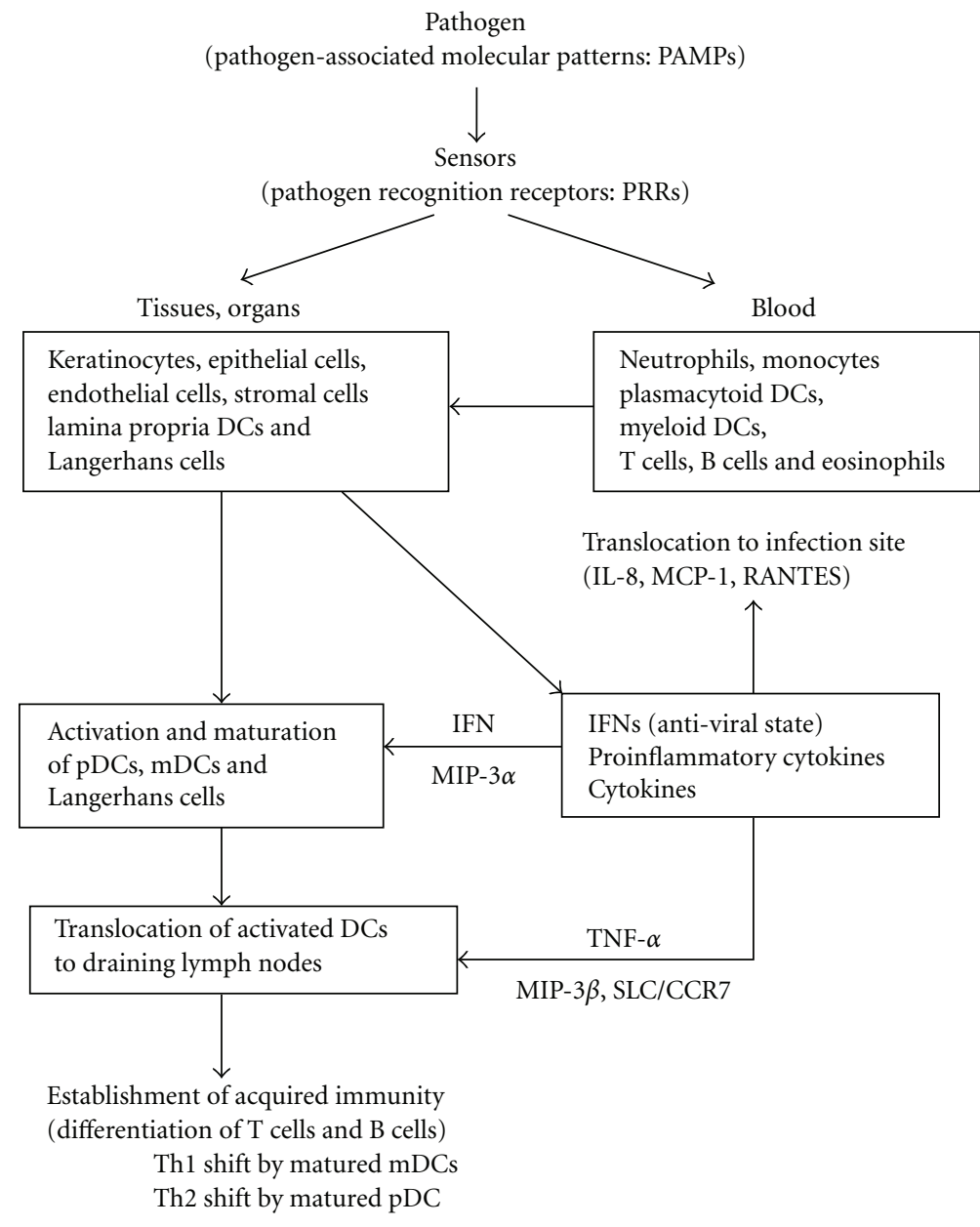

Figure 1: Process of innate immunity to acquired immunity.

can infect $\mathrm{CD}^{+} \mathrm{T}$ lymphocytes, monocytes, macrophages, and DCs, and preferentially replicates in activated T lymphocytes and activated macrophages. It replicates generally much more slowly in DCs regardless of maturation stage. HIV establishes a latent infection in resting T lymphocyte, and T lymphocyte activation by DCs or stimulation with IL2 is thought to trigger active replication of the virus. Resting T lymphocytes show resistance to infection and proliferation of HIV. Apolipoprotein B mRNA editing enzyme catalytic polypeptide-like 3G (APOBEC3G) is important for this resistance $[16,17]$. The antiviral mechanisms of APBEC3G are considered to act via inhibition of viral reverse transcriptase (RT). It also produces a transition ( $G$ to $A$ ) in the DNA strand transcribed by RT due to its cytidine deaminase activity. However, a mutant lacking cytidine deaminase retains antiviral activity. Low molecular weight complexes of APOBEC3G (LMM: $70-100 \mathrm{kDa}$ ) have antiviral activity, but high molecular weight complexes (HMM: $700 \mathrm{kDa}$ ) do not. The Vif protein of HIV converts LMM to HMM, and promotes proteasome-dependent degradation of the complex, so HIV can counteract its antiviral activity [18]. T cell activation leads to conversion of LMM to HMM (proviral environment). On the other hand, IFNs induce LMM type (antiviral environment) $[19,20]$.
During the early stage of HIV infection, clinical symptoms show sings of immune system activation such as flu-like symptoms, rather than immunosuppression. Immunological activation is caused by RNA40, an oligonucleotide derived from HIV, which activates pDCs, mDCs, T lymphocytes, and monocytes via TLR7 and TLR8 [21]. The virus proteins, Tat and $\mathrm{Vpr}$, induce proinflammatory cytokines via activation of NF- $\kappa \mathrm{B}[22,23]$, which then enhances the transcription of the virus genome via the LTR. IL-8 also contributes to the propagation of the virus via the accumulation of $\mathrm{T}$ lymphocytes.

Enhanced proliferation of HIV causes immune responses that attempt to eliminate the virus. So, HIV maintains a latent infection in order to survive within the host. The Vpu protein suppresses NF- $\kappa$ B activation by inhibition of proteasome-dependent degradation of $\mathrm{I} \kappa \mathrm{B}$ [24]. The Nef protein suppresses phosphorylation of ERK through induction of a phosphatase MKP-1 [25]. This causes suppression of TNF- $\alpha$ production by macrophages via TLR4 signaling. Because TNF- $\alpha$ is necessary for maturation and translocation of DCs (including Langerhans cells) to the lymph nodes, downregulation of TNF- $\alpha$ leads to suppression of acquired immune responses, and so prevents inhibition of virus proliferation by activated T lymphoctes. Furthermore, Nef 
TABLE 1: Molecular mechanisms involved in modulation of host innate immune systems by viruses.

\begin{tabular}{|c|c|c|c|}
\hline Virus/Virus protein & Host pathway & Function & Effect \\
\hline \multicolumn{4}{|l|}{ RNA virus } \\
\hline \multicolumn{4}{|c|}{ Human immunodeficiency virus (HIV) } \\
\hline \multirow[t]{2}{*}{ Nef } & TCR-CD30 & $\begin{array}{l}\text { Inhibit NF- } \kappa \text { B and AP-1 } \\
\text { activation }\end{array}$ & Inhibit $\mathrm{T}$ cell activation \\
\hline & TLR4 & $\begin{array}{l}\text { Inhibit ERK activation } \\
\text { (Dephosphorylation of } \\
\text { ERK by induced MKP-1) }\end{array}$ & Suppress TNF- $\alpha$ production \\
\hline Vpu & TLRs & $\begin{array}{l}\text { Inhibit NF- } \kappa \mathrm{B} \text { activation } \\
\text { (Stabilize } \mathrm{I} \kappa \mathrm{B} \text { ) }\end{array}$ & Suppress cytokine production \\
\hline Tat & & $\begin{array}{l}\text { Activate NF- } \kappa \mathrm{B} \\
\text { (PKR-dependent) }\end{array}$ & \\
\hline Vpr & & Activate NF- $\kappa$ B & $\begin{array}{l}\text { Enhance IL-6, IL-8, and IL-10 } \\
\text { production }\end{array}$ \\
\hline RNA40 & TLR7/8 & $\begin{array}{l}\text { Activate IRF- } 7 \text { mediated by } \\
\text { MyD } 88\end{array}$ & Activate pDCs \\
\hline \multicolumn{4}{|c|}{ Human T-lymphotropic leukemia virus 1 (HTLV-1) } \\
\hline p30 & TLR4 & $\begin{array}{l}\text { Suppress TLR4 expression } \\
\text { (Suppress PU.1 fuction) }\end{array}$ & Suppress cytokine production \\
\hline & & Inhibit GSK3- $\beta$ & Enhance IL-10 production \\
\hline p12 & TCR & $\begin{array}{l}\text { Suppress phosphorylation } \\
\text { of PLC- } \gamma 1 \text { and Vav }\end{array}$ & $\begin{array}{l}\text { Suppress T cell activation by } \\
\text { DCs }\end{array}$ \\
\hline Tax & & $\begin{array}{l}\text { Activate IKK (Bind to } \\
\text { IKK } \gamma \text { ) }\end{array}$ & $\begin{array}{l}\text { Induce IL-2, IL-2R, GM-CSF, } \\
\text { and IL-15 }\end{array}$ \\
\hline \multicolumn{4}{|c|}{ Hepatitis C virus (HCV) } \\
\hline NS3/4A & TLR3/4 & Degrade TRIF & Suppress IFN- $\alpha / \beta$ production \\
\hline & & & $\begin{array}{l}\text { Suppress } \mathrm{CD} 4^{+} \mathrm{T} \text { cell } \\
\text { activation by dysfunction of } \\
\text { mDCs }\end{array}$ \\
\hline \multirow[t]{2}{*}{ NS5A } & TLRs & $\begin{array}{l}\text { Inhibit NF- } \kappa \text { B activation } \\
\text { (Bind to MyD88) }\end{array}$ & Suppress cytokine production \\
\hline & & $\begin{array}{l}\text { Inhibit JNK activation } \\
\text { (Bind to TRAF2) }\end{array}$ & $\begin{array}{l}\text { Suppress TNF pathway } \\
\text { activation }\end{array}$ \\
\hline core, NS3 & TLR2 & $\begin{array}{l}\text { Activate MAP kinase } \\
\text { pathway, NF- } \kappa \mathrm{B} \text {, and AP-1 }\end{array}$ & $\begin{array}{l}\text { Dysfunction of pDCs by } \\
\text { enhanced production of IL-10 } \\
\text { and TNF- } \alpha\end{array}$ \\
\hline \multicolumn{4}{|l|}{ Measles virus } \\
\hline $\mathrm{N}(?)$ & & & $\begin{array}{l}\text { Suppress IL-12 production } \\
\text { mediated by TLR4 in DCs } \\
\text { (Suppress Th1 differentiation) }\end{array}$ \\
\hline $\mathrm{P}$ & $\mathrm{TLR} 2 / 4$ & $\begin{array}{l}\text { Suppress NF- } \kappa \text { B and AP-1 } \\
\text { activation (Upregulate host } \\
\text { NF- } \kappa \text { B negative regulator } \\
\text { A20) }\end{array}$ & $\begin{array}{l}\text { Inhibit proinflammatory } \\
\text { cytokine and chemokine } \\
\text { production }\end{array}$ \\
\hline HA & TLR2 & Activate NF- $\kappa \mathrm{B}$ & Induce cytokine production \\
\hline \multicolumn{4}{|l|}{ Influenza virus A } \\
\hline \multirow[t]{3}{*}{ NS1 } & TLR3/7/9 & $\begin{array}{l}\text { Suppress of IRF3/7 } \\
\text { activation }\end{array}$ & $\begin{array}{l}\text { Inhibit IFN production in } \\
\text { pDC }\end{array}$ \\
\hline & TLR4 & $\begin{array}{l}\text { Suppress of NF- } \kappa \text { B and } \\
\text { AP- } 1 \text { activation }\end{array}$ & $\begin{array}{l}\text { Suppress DC and T cell } \\
\text { activation }\end{array}$ \\
\hline & RIG-I & $\begin{array}{l}\text { Suppress of IRF3/7 } \\
\text { activation }\end{array}$ & $\begin{array}{l}\text { Inhibit IFN production in } \\
\text { mDC }\end{array}$ \\
\hline
\end{tabular}


TABle 1: Continued.

\begin{tabular}{|c|c|c|c|}
\hline Virus/Virus protein & Host pathway & Function & Effect \\
\hline \multicolumn{4}{|c|}{ SARS-coronavirus (SARS-CoV) } \\
\hline \multirow[t]{2}{*}{ 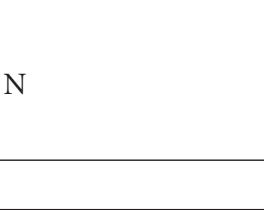 } & & $\begin{array}{l}\text { Activate AP-1 } \\
\text { Bind to NF- } \kappa \text { B and C/EBP } \\
\text { binding motifs of IL- } 6 \\
\text { promoter }\end{array}$ & Induce IL-6 and COX-2 \\
\hline & promoter & & \\
\hline \multicolumn{4}{|c|}{ Human respiratory syncytial virus (RSV) } \\
\hline G & $\mathrm{TLR} 2 / 4 / 9$ & Suppress NF- $\kappa$ B activation & Suppress cytokine production \\
\hline $\mathrm{F}$ & TLR4 & Activate NF- $\kappa \mathrm{B}$ & $\begin{array}{l}\text { Induce IL-1, IL-6, IL-8, and } \\
\text { RANTES }\end{array}$ \\
\hline M2-1 & & Activate NF- $\kappa \mathrm{B}$ & \\
\hline$?$ & TLR7/9 & & $\begin{array}{l}\text { Suppress IFN production in } \\
\text { pDC }\end{array}$ \\
\hline NS1, NS2 & TLR3/4, RIG-I & Suppress IRF3 activation & $\begin{array}{l}\text { Suppress IFN production in } \\
\text { mDC }\end{array}$ \\
\hline
\end{tabular}

\section{Rotavirus}

VP4

Activate NF- $\kappa \mathrm{B}$

Suppress JNK

(Bind to TRAF2)

\section{DNA virus}

Vaccinia virus

A46R

A52R

TLRs

N1L

TLRs
Suppress NF- $\kappa$ B activation (Bind to MyD88, TRAM, and TRIF)

Suppress NF- $\kappa$ B activation (Bind to IRAK2)

Activate p38 MAPK and

JNK (Bind to TRAF6)

Suppress NF- $\kappa$ B activation

(Bind to IKK $\gamma$ )

Suppress IRF3 activation

(Bind to TBK1)

\section{Adenovirus}

RID

TLR4

TNF pathway

capsid
Suppress NF- $\kappa$ B and AP-1 activation

Suppress TNFR1

expression

Activate NF- $\kappa \mathrm{B}$, ERK, and MAPK
Suppress cytokine production

Suppress cytokine production

Induce IL-10 production

Suppress cytokine production

Suppress IFN production

Suppress MCP-1 and IL-8 production

Suppress MCP-1 and IL-8 production

Induce RANTES and IL-10

Herpes simplex virus (HSV)

virion TLR2

Induce cytokine production

viral DNA

TLR9

Induce IFN production

Varicella-zoster virus

vrion

TLR2

Induce cytokine production

Human cytomegalovirus (HCMV)

late proteins

IL-1 system

TNF system

$\mathrm{gB} / \mathrm{gH}$
TLR2/1
Suppress NF- $\kappa$ B activation

(Inhibit site located upstream of MAP3K)

Suppress TNFR1

expression

Activate NF- $\kappa \mathrm{B}$
Produce proinflammatory cytokines 
TABLE 1: Continued.

\begin{tabular}{|c|c|c|c|}
\hline Virus/Virus protein & Host pathway & Function & Effect \\
\hline \multicolumn{4}{|c|}{ Epstein-Barr virus (EBV) } \\
\hline late protein & & Suppress NF- $\kappa$ B activation & Inhibit COX-2 activation \\
\hline gp350/gp220 & TLR2/CD21 & Activate NF- $\kappa \mathrm{B}$ & Induce $\mathrm{MCP}-1$ production \\
\hline LMP-1 & & $\begin{array}{l}\text { Activate p38 MAPK } \\
\text { (TRAF6-dependent) }\end{array}$ & $\begin{array}{l}\text { Suppress DC function by } \\
\text { induced IL-10 }\end{array}$ \\
\hline \multicolumn{4}{|c|}{ Human herpesvirus 8 (HHV8) } \\
\hline vFLIP & & $\begin{array}{l}\text { Activate IKK } \\
(\text { Bind to IKK } \gamma \text { ) }\end{array}$ & \\
\hline RTA & & $\begin{array}{l}\text { Degrade IRF7 by } \\
\text { proteasome system }\end{array}$ & Suppress IFN- $\alpha / \beta$ production \\
\hline \multicolumn{4}{|l|}{ Hepatitis B virus } \\
\hline e antigen & IL-1 pathway & $\begin{array}{l}\text { Activate NF- } \kappa \mathrm{B} \\
\text { (Bind to mIL-1RAcP) }\end{array}$ & $\begin{array}{l}\text { Induce cytokine } \\
\text { production }\end{array}$ \\
\hline
\end{tabular}

inhibits T cell receptor induced lymphocyte activation [26]. These strategies contribute to the suppression of HIV proliferation in the lymph nodes, and also inhibit the propagation of infection. Other immunosuppressive mechanisms used by HIV have also been reported. Cosuppressive molecules, such as B7-H1 on DCs and PD1 on T lymphocytes, are upregulated in patients with HIV, and induce apoptosis through their interaction with DCs and T lymphocytes. In addition, HIV is thought to induce regulatory T cells [27].

3.3. Hepatitis C Virus (HCV). HCV does not only infect hepatocytes. It can also infect DCs, macrophages, monocytes, and T lymphocytes. However, the virus does not replicate efficiently in these cell types. Although, virus particles and virus proteins are found in the blood of $\mathrm{HCV}$ patients. HCV causes no cytopathic effects. Immune responses against HCV may be weak, but infected cells are attacked and eliminated. In order to survive in the host, HCV maintains a chronic infection by suppressing the host immune responses. Both $\mathrm{HCV}$ core and NS3 proteins activate NF- $\kappa \mathrm{B}$ and AP-1 via stimulation of TLR2, which requires TLR1 and TLR6 as costimulators, in monocytes and Kupffer cells [28]. This activation leads to the production of IL-10 and TNF- $\alpha$, both found in HCV patients at a high titer. IL-10 suppresses the maturation of pDCs and the activation of T lymphocytes, and induces apoptosis in pDCs. The NS3NS4A protein complex, which is a serine protease, degrades TRIF and IPS-1/Cardif/MAVS/VISA, which are essential for cellular signaling via TLR3, TLR4, and RIG-I [29]. This shutting off of TRIF- and IPS-1-dependent signaling results in the suppression of IFN- $\alpha$ and IFN- $\beta$ production, and in dysfunction of mDCs.

The NS5A protein suppresses activation of IRAK-1 through its interaction with MyD88. This leads to the shutting off of TLR7 and TLR8 signaling, and to the suppression of maturation and differentiation of pDCs [30]. On the other hand, NF5A suppresses TRAF2 dependent NF$\kappa \mathrm{B}$ activation via interaction with NF5A and TRAF2, but suppress neither MEK1 activation nor IKK $\beta$-dependent NF$\kappa \mathrm{B}$ activation [31]. TNF- $\alpha$-dependent activation of JNK is enhanced. Infected DCs are thought to affect the production of TNF- $\alpha$, TNF- $\alpha$ signal transduction, and chemotaxsis and maturation. Dysfunction of DCs, suppression of $\mathrm{T}$ lymphocyte activation, and a decrease in DC number due to apoptosis allow HCV to establish a chronic infection [32]. It has also been reported that HCV-specific cytotoxic $\mathrm{T}$ lymphocytes share upregulated expression of the coinhibitory molecule PD-1, and that signaling from PD-1L (PD1 ligand) on DCs results in suppression of $\mathrm{HCV}$-specific cytotoxic T lymphocytes [33].

3.4. Measles Virus. Measles virus infection causes strong immunosuppression. Measles virus wild strains (clinical isolates) recognize CD150/SLAM (signaling lymphocyte activation molecule) as a receptor. However, laboratory (vaccine) strains only recognize CD46. SLAM is strongly expresseed on memory $\mathrm{T}$ cells and $\mathrm{B}$ cells, but is also expressed on monocytes, T cells, B cells, and matured DCs. SLAM is not expressed on immature DCs, epithelial cells, and endothelial cells. On the other hand, CD46 is expressed on variety of cell types. Infection of SLAM-negative mucosal epithelial cells with measles virus wild strains is thought to be mediated by an as yet unknown "third" receptor [34, 35]. The HA protein of wild virus strain, but not the laboratory strain, induces cytokines such as IL- $1 \alpha$, IL- $1 \beta$, IL-6, IL-8, and IL-12 via the TLR2 signaling pathway [36]. These cytokines activate and recruit immune cells to the site of inflammation, where the activated immune cells are infected with measles virus via SLAM. The infection and cytokine production are thus propagated.

Interaction of the HA protein with SLAM suppresses TLR4-mediated IL-12 production, but not IL- 6 and TNF- $\alpha$ production. However, IL-12 production mediated by other TLR signaling pathways (i.e., not via TLR4) is unaffected by the HA protein [37]. These observations suggest that SLAM is a coupling factor for TLR4, and that the HA protein inhibits this function. The HA protein also interacts with a C-type lectin, dendritic cell-specific ICAM-3grabbing nonintegrin (DC-SIGN) on DCs, and activates the serine/threonine protein kinase Raf-1 via the Ras signaling 


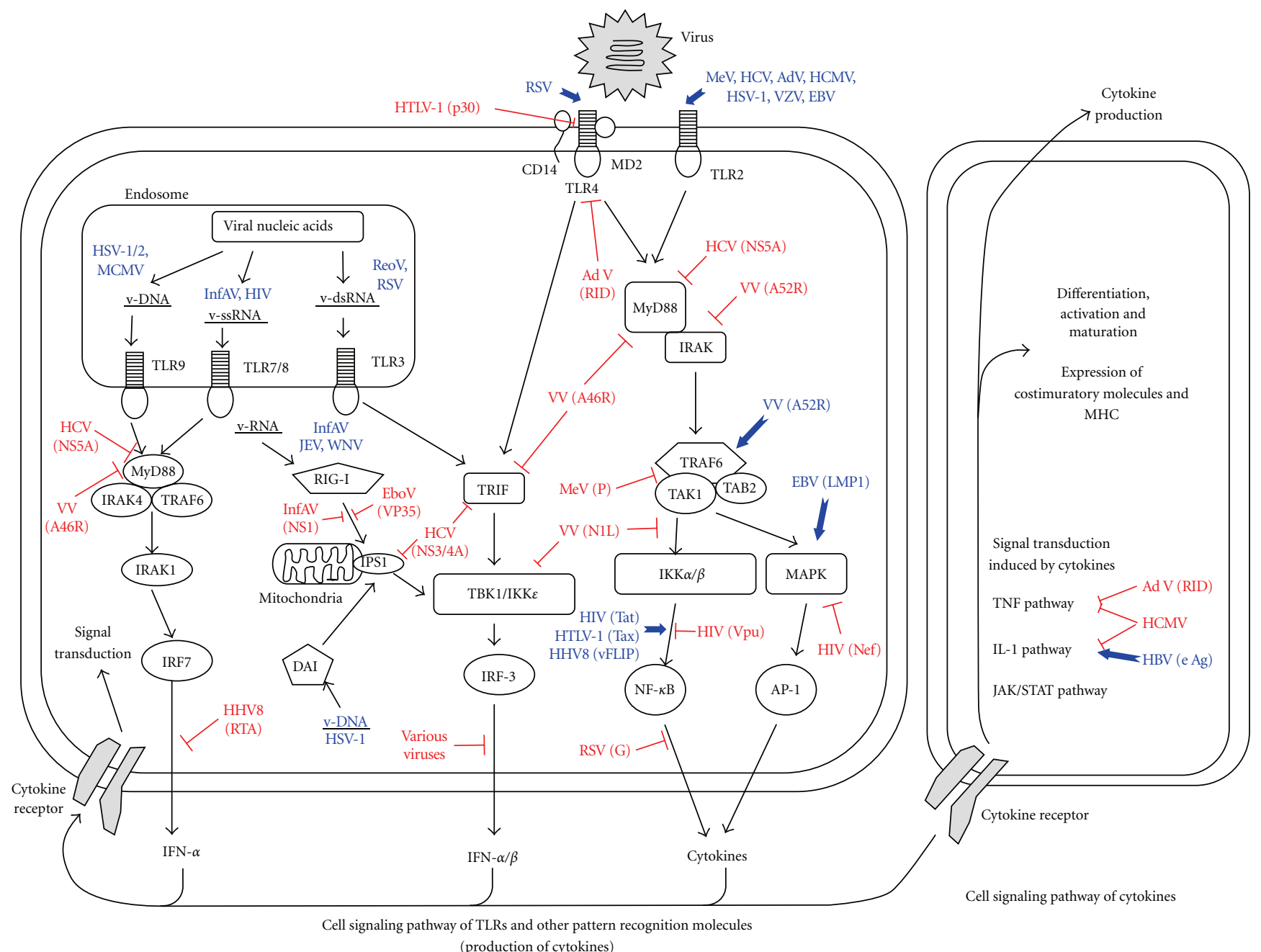

$\begin{array}{ll}\text { AdV: Adenovirus } & \text { HCMV: Human cytomegalovirus } \\ \text { EBV: Epstein-Barr virus } & \text { HCV: Hepatitis C virus } \\ \text { EboV: Eboravirus } & \text { HHV8: Human herpesvirus } 8 \\ \text { HBV: Hepatitis B virus } & \text { HIV: Human immunodeficiency virus } \\ \text { ReoV: Reovirus } & \text { RSV: Human respiratory syncytial virus } \\ \text { WNV: West Nile virus } & \end{array}$

HTLV-1: Human T-lymphotropic virus 1 InfAV: Influenzavirus A JEV: Japanese encephalitis virus $\mathrm{MeV}$ : Measles virus VV: Vaccinia virus

FIgURE 2: Modulation of TLR and other PAMP-induced signal transduction pathways by virus infection. Red line indicates suppression by virus. Blue line indicates activation by virus. Parenthesises denote viral proteins ornucleic acids.

pathway. DC-SIGN-mediated Raf-1 activation induces phosphorylation of NF- $\kappa$ Bp65 on Ser-276, and its subsequent acetylation. This leads to the enhanced transcription of IL-10 [38]. During infection stage that virus proteins are synthesized de novo, the host cells, such as monocytes and DCs, infected with measles virus show suppressed IL12 production and TLR signaling, via TLR2, TLR4, TLR7, and TLR9. pDCs infected with the measles virus showed suppressed IFN production and dysfunction of maturation $[39,40]$.

Both monocytic cell lines U937 and THP-1 and human peripheral blood mononuclear cells infected with measles virus show markedly suppressed TLR2- and TLR4-mediated proinflammatory cytokine induction via NF- $\kappa$ B and AP-1 [41]. However, epithelial cells infected with measles virus show constitutive activation of NF- $\kappa \mathrm{B}$ and proinflammatory cytokine production, and these are further enhanced by treatment with TLR agonists such as lipopolysaccharide (LPS). Monocytic cell lines infected with the mumps virus, which also belongs to the Orthomyxoviridae family, show constitutive activation of NF- $\kappa \mathrm{B}$ and constitutively high levels of IL-8 production. In monocytic cells infected with the measles virus, LPS-induced ubiquitination (probably K63linked type) of TNF receptor-associated factor 6 (TRAF6) is suppressed and does not form active complexes of TAK1, TAB2, and TRAF6. An ubiquitin-modifying enzyme A20, 
which is a host NF- $\kappa \mathrm{B}$ negative regulator, is upregulated in measles virus-infected monocytic cells, but not in infected epithelial cells. The promoter region of the A20 gene shares two NF- $\kappa \mathrm{B}$ binding sites and a negative regulatory motif, ELIE, which is located upstream of, and adjacent to the two NF- $\kappa \mathrm{B}$ binding motifs. Measles virus $\mathrm{P}$ protein (phosphoprotein) interacts with the ELIE motif, and activates transcription of A20. P protein is thought to release the suppressed A20 transcription machinery independently of activated NF- $\kappa \mathrm{B}$ [42]. The reason for cell-type specific A20 expression is unclear. However, the measles virus $\mathrm{V}$ protein, which is formed by RNA editing of the $\mathrm{P}$ genome and has an $\mathrm{N}$ terminal amino acid sequence identical to that of $\mathrm{P}$ protein, does activate NF- $\kappa \mathrm{B}$. The balance of the expression levels and time courses of the $\mathrm{P}$ and $\mathrm{V}$ proteins may also contribute to the cell-type specific suppression of TLR signaling pathways.

3.5. Influenza Virus. The NS1 protein of type A influenza viruses suppresses innate immune system signaling activated by the PAMPs, via TLR3, TLR4, RIG-I, and MDA5 system. The suppression should contribute to efficient replication of infected virus in respiratory epithelial. The mechanism of suppression is mainly via inhibition of IRF-3 phosphorylation [43], leading to suppressed induction of IFN- $\alpha / \beta$, and IFN- $\lambda 1,2$, and 3 . In addition, inhibition of NF- $\kappa$ B and AP- 1 activation in influenza virus infected cells leads to suppressed proinflammatory cytokine production, for example, IL-8 and TNF- $\alpha$. Influenza virus NS1 protein is known to be a multifunctional protein able to inhibit the type I IFN induction, the IFN-induced antiviral activity, the binding and sequestration of dsRNA, the interference with the host mRNA processing, the facilitation of preferential viral mRNA translation, and the inhibition of DC activation $[44,45]$.

3.6. Human Respiratory Syncytial Virus (RSV). RSV F protein causes TLR4-mediated NF- $\kappa \mathrm{B}$ activation during the early infection stages of infection that is dependent upon virus replication. IL- $1 \beta$, IL- 6 , and IL- 8 are induced via NF$\kappa \mathrm{B}$ activated by the stimulation of TLR4. During the late stages, the viral G protein is produced, and secreted, which then suppresses TLR4-mediated signal transduction [46]. The cysteine-rich (GCRR) region of the G protein is also important for NF- $\kappa \mathrm{B}$ suppression. Following the interaction of virus proteins with host cell surface proteins, the viral M21 protein inhibits the translocation of RelA, a component of NF- $\kappa \mathrm{B}$, to the cell nucleus [47]. Expression of the viral nonstructural proteins, NS1 and NS2 inhibit activation of IRF3 induced by TLR3, TLR4, and RIG-I signaling, and also suppress IFN production [48]. However, NS1 and NS2 proteins have little effect on NF- $\kappa \mathrm{B}$ or AP-1 activation, so the production of proinflammatory cytokines may be effectively induced in the RSV-infected cells.

\section{DNA Virus}

4.1. Vaccinia Virus. Orthopox viruses, including the vaccinia virus, produce proteins that mimic cytokine receptors, such as those for IFN- $\alpha$, IFN- $\beta$, IFN- $\gamma$, IL- $1 \beta$, IL-18, and TNF$\alpha$, and disturb the cytokine signal transduction system. Other viral proteins also disturb the intracellular signal transduction systems. The viral A46R protein has a TIR domain, and interacts with MyD88 and TRIF, suppressing both IL- 1 and TLR signal transduction, but not TNF- $\alpha$ signal transduction [49]. The viral A52R protein binds to IRAK2, suppresses TRAF6-dependent IKK and NF- $\kappa$ B activation, and then inhibits production of IL-8 and RANTES. However, A52R also binds to TRAF6 and promotes polyubiquitination of TRAF6, TAK1 activation, MAPKK6 phosphorylation, and activation of the JNK-p38 MAP kinase pathway. The later leads to the induction of IL-10 production [50]. The viral N1L protein interacts with the IKK complex (IKK $\alpha$-IKK $\beta$ $\mathrm{IKK} \gamma$ ), TBK1, and $\mathrm{IKK} \varepsilon$, and then suppresses the activation of NF- $\kappa$ B and IRF-3 [51]. Vaccinia virus not only suppresses proinflammatory cytokines, but also induces production of an immunosuppressive cytokine IL-10, which shifts the Th1 response and suppresses cellular immunity. Human monocytes infected with vaccinia virus produce IL-10, and this IL10 is then further upregulated by stimulation with LPS [52].

4.2. Adenovirus. During the early stages of infection, adenovirus particles induce the MyD88-dependent production of RANTES, IP-10, and MIP-1 [53]. The cytokines produced enhance both sensitivity to LPS and the production of TNF- $\alpha$. TNF- $\alpha$ suppresses the formation and maturation of virus particles, and induces apoptosis of infected cells. TNF- $\alpha$ also promotes the chemotaxis and maturation of dendritic cells. The induction of TNF- $\alpha$ is considered to be a host defense response. On the other hand, the adenovirus E1A and E3 proteins inhibit TNF- $\alpha$-induced apoptosis. The receptor internalization and degradation (RID) complex, which consists two E3 products, E3(10.4k)/RID $\alpha$ and E3 $(14.5 \mathrm{k}) / \mathrm{RID} \beta$, suppresses cell surface expression of Fas, TNF-related apoptosis-inducing ligand (TRAIL) receptor 1 , TRAIL receptor 2 , and TNF receptor $1[54,55]$. This results in the shutting down of the TNF- $\alpha$-mediated signaling pathways in the infected cells. RID also suppresses the TLR4 signaling pathway. LPS-induced MCP- 1 and IL- 8 production are suppressed through the inhibition of NF- $\kappa$ B and AP-1 activation [56]. RID does not alter the expression levels of TLR4, and so is thought to affect other components of the TLR signal transduction pathway.

4.3. Human Cytomegalovirus (HCMV). HCMV modulates $\mathrm{NF}-\kappa \mathrm{B}$ activity during the various stages of infection. During the early stages, the membrane glycoproteins $\mathrm{gB}$ and $\mathrm{gH}$ interact with TLR2 and activate NF- $\kappa \mathrm{B}$ [57]. NF$\kappa \mathrm{B}$ then contributes to the induction of proinflammatory cytokines, to the expression of virus immediate early genes, and to the replication of the viral genome. The viral US28 protein, which is a HCMV-encoded chemokine receptor, constitutively activates both $\mathrm{NF}-\kappa \mathrm{B}$ and phospholipase $C$ signaling pathways [58]. The activated NF$\kappa \mathrm{B}$ mediates the upregulation of the host serine/threonine protein kinase, receptor-interacting protein-like interacting caspase-like apoptosis regulatory protein kinase (RICK). 
RICK, which has a caspase-recruitment (CARD) domain, functions downstream of the pattern recognition receptors (which include the TLR, RLR, and NLR family members) and mediates NF- $\kappa \mathrm{B}$ and MAP kinase activation. RICK suppresses the replication of HCMV in cooperation with active NF- $\kappa$ B and IFN- $\beta$ [59]. Not to be outdone, the late gene products of HCMV also suppress NF- $\kappa$ B activation [60, 61 ]. TNF- $\alpha$ signaling is suppressed through downregulation of TNF receptor 1. IL-6, IL-8, and MCP are not induced in HCMV-infected cells and chemotaxsis, activation, and maturation are all suppressed.

4.4. Epstein-Baar Virus (EBV). EBV mainly infects B cells, although it can also infect T cells, NK cells, and epithelial cells. Both the attachment of EBV to receptor CD21 and the interaction of the virus glycoprotein gp350-gp250 with TLR2 activate NF- $\kappa \mathrm{B}$ [62]. The virus $\mathrm{gB}$ and $\mathrm{gH}$ proteins are also candidates for TLR2 ligands. Immortalization of B cells by EBV infection is due to the activation of NF- $\kappa \mathrm{B}$ by the latent membrane protein 1 (LMP1), and antigen stimulation-like signaling of the B cell receptor by LMP-2. TLR2 signaling suppresses the transcription of the TLR9 gene via activation of NF- $\kappa \mathrm{B}$ containing p65 protein. So downregulation of TLR9 and upregulation of TLR7 and MyD88 are observed in EBV-infected cells [63]. Cell proliferation is thought to be driven by TLR7 signaling activated by virus RNA, because the TLR7 antagonist IRS661 suppresses cell division. Small RNA encoded by the EBV genome (EBV-EBERs) activates TLR7 signaling, and induces IL-10 production. TLR7 signaling also upregulates and activates IRF-5, and induces proinflammatory cytokines. However, activated IRF5 is negatively regulated by EBV-induced IRF- 4 and a splice variant of IRF-5 (V12IRF-5) [63]. This suggests that the TLR7 signaling system play a role in the cell division of EBVinfected cells, and in the establishment of persistent infection. Lytic infection and production of virus particles are observed during the late stage of EBV infection. Late proteins suppress NF- $\kappa \mathrm{B}$ activation. This leads to the downregulation of proinflammatory cytokines, the upregulation of TLR9, and the suppression of TLR7 function through interaction of TLR7 and TLR9. So the TLR9 system should be important during late stage of EBV infection.

\section{Concluding Remarks}

Viruses are in a constant battle with the host immune system. Viruses modulate both the innate and acquired immune systems using a number of clever strategies. The goal appears to be to survive within the host for a long time, rather than efficient replication. Excessive replication would lead to detection and elimination by the host innate and acquired immune systems, thus bringing about the death of the virus. The virus needs to strike a balance between activation and suppression of host immune response. It is likely that each virus has developed various strategies to modulate the host immune response individually, and viruses that have succeeded in creating a good balance between host and parasite have survived.
Modification of TLR signaling is a promising strategy for treatment of cancer, allergy, and infectious diseases [64, 65]. Especially, the immunomodulators should not generate resistant virus to drugs compared to antiviral drugs targeting viral proteins. As an existing example of virus infection, imiquimod, which is a TLR7 agonist, have been applied to an infectious disease caused by human papilloma virus, namely, condylomata acuminata [66]. TLR4 antagonists are trying to be applied to treatment of sepsis. Several issues must be considered for the clinical application of TLR signaling. Among the greatest is assessment of what are keys of host defense or virus survival in view of a series of viral infection process. For example, human herpes simplex virus 1 (HSV-1) requires activated NF- $\kappa \mathrm{B}$ for its efficient replication [67]. On the other hand, NF- $\kappa \mathrm{B}$ has a key role in inflammatory reactions via transcription activation of proinflammatory cytokines, cell adhesion molecules, and MHC. Thus, activation of NF- $\kappa \mathrm{B}$ is a double-edged sword for HSV-1. In the host side, TLR signaling varies according to organs and tissues. For example, intestinal epithelial cells express low levels of TLRs and high levels of negative regulators of TLR signaling, such as Tollip $[68,69]$. Also, in intestinal immunity, NF- $\kappa$ B activation in a subset TLR signaling in DCs and macrophages is suppressed by a negative regulation I $\kappa$ BNS [70]. The dysregulation of TLR signaling in the lumen of intestinal epithelial causes limit chronic inflammatory activation induced by commensal bacteria. Various TLR polymorphisms have been found, and some of them are shown to contribute to dysregulation of TLR signaling. The dysregulation has been suggested to be linked with a number of disease sensitivity and condition depending on individual differences [71, 72].

In conclusion, the molecular mechanisms involved in modulation of host immune systems, including TLR signaling, give us important hints on how to overcome infectious diseases caused by viruses.

\section{References}

[1] T. Kawai and S. Akira, "The roles of TLRs, RLRs and NLRs in pathogen recognition," International Immunology, vol. 21, no. 4, pp. 317-337, 2009.

[2] O. Takeuchi and S. Akira, "Innate immunity to virus infection," Immunological Reviews, vol. 227, no. 1, pp. 75-86, 2009.

[3] O. Takeuchi and S. Akira, "MDA5/RIG-I and virus recognition," Current Opinion in Immunology, vol. 20, no. 1, pp. 1722, 2008.

[4] N. Inohara and G. Nunez, "NODS: intracellular proteins involved in inflammation and apoptosis," Nature Reviews Immunology, vol. 3, no. 5, pp. 371-382, 2003.

[5] A. Takaoka, Z. Wang, M. K. Choi, et al., "DAI (DLM-1/ZBP1) is a cytosolic DNA sensor and an activator of innate immune response," Nature, vol. 448, no. 7152, pp. 501-505, 2007.

[6] K. L. McGuire, V. E. Curtiss, E. L. Larson, and W. A. Haseltine, "Influence of human T-cell leukemia virus type I tax and rex on interleukin-2 gene expression," Journal of Virology, vol. 67, no. 3, pp. 1590-1599, 1993.

[7] F. Bex and R. B. Gaynor, "Regulation of gene expression by HTLV-I tax protein,” Methods, vol. 16, no. 1, pp. 83-94, 1998. 
[8] M. D. Robek and L. Ratner, "Immortalization of $\mathrm{CD}^{+}$and $\mathrm{CD}^{+} \mathrm{T}$ lymphocytes by human $\mathrm{T}$-cell leukemia virus type 1 Tax mutants expressed in a functional molecular clone," Journal of Virology, vol. 73, no. 6, pp. 4856-4865, 1999.

[9] R. Kubota, Y. Furukawa, S. Izumo, K. Usuku, and M. Osame, "Degenerate specificity of HTLV-1-specific $\mathrm{CD}^{+} \mathrm{T}$ cells during viral replication in patients with HTLV-1-associated myelopathy (HAM/TSP)," Blood, vol. 101, no. 8, pp. 3074 3081, 2003.

[10] Y. Satou, J. Yasunaga, M. Yoshida, and M. Matsuoka, "HTLV-I basic leucine zipper factor gene mRNA supports proliferation of adult T cell leukemia cells," Proceedings of the National Academy of Sciences of the United States of America, vol. 103, no. 3, pp. 720-725, 2006.

[11] H. H. Baydoun, M. Bellon, and C. Nicot, "HTLV-1 Yin and Yang: rex and p30 master regulators of viral mRNA trafficking," AIDS Reviews, vol. 10, no. 4, pp. 195-204, 2008.

[12] V. Haehnel, L. Schwarzfischer, M. J. Fenton, and M. Rehli, "Transcriptional regulation of the human Toll-like receptor 2 gene in monocytes and macrophages," Journal of Immunology, vol. 168, no. 11, pp. 5629-5637, 2002.

[13] M. Rehli, A. Poltorak, L. Schwarzfischer, S. W. Krause, R. Andreesen, and B. Beutler, "PU.1 and interferon consensus sequence-binding protein regulate the myeloid expression of the human Toll-like receptor 4 gene," Journal of Biological Chemistry, vol. 275, no. 13, pp. 9773-9781, 2000.

[14] A. Datta, U. Sinha-Datta, N. K. Dhillon, S. Buch, and C. Nicot, "The HTLV-I p30 interferes with TLR4 signaling and modulates the release of pro- and anti-inflammatory cytokines from human macrophages," Journal of Biological Chemistry, vol. 281, no. 33, pp. 23414-23424, 2006.

[15] R. Fukumoto, M. Dundr, C. Nicot, et al., "Inhibition of T-cell receptor signal transduction and viral expression by the linker for activation of T cells-interacting $\mathrm{p} 12^{\mathrm{I}}$ protein of human Tcell leukemia/lymphoma virus type 1," Journal of Virology, vol. 81, no. 17, pp. 9088-9099, 2007.

[16] Y.-L. Chiu and W. C. Greene, "APOBEC3 cytidine deaminases: distinct antiviral actions along the retroviral life cycle," Journal of Biological Chemistry, vol. 281, no. 13, pp. 8309-8312, 2006.

[17] Y.-L. Chiu and W. C. Greene, "The APOBEC3 cytidine deaminases: an innate defensive network opposing exogenous retroviruses and endogenous retroelements," Annual Review of Immunology, vol. 26, pp. 317-353, 2008.

[18] A. M. Sheehy, N. C. Gaddis, and M. H. Malim, "The antiretroviral enzyme APOBEC3G is degraded by the proteasome in response to HIV-1 Vif," Nature Medicine, vol. 9, no. 11, pp. 1404-1407, 2003.

[19] G. Peng, K. J. Lei, W. Jin, T. Greenwell-Wild, and S. M. Wahl, "Induction of APOBEC3 family proteins, a defensive maneuver underlying interferon-induced anti-HIV-1 activity," Journal of Experimental Medicine, vol. 203, no. 1, pp. 41-46, 2006.

[20] K. Chen, J. Huang, C. Zhang, et al., "Alpha interferon potently enhances the anti-human immunodeficiency virus type 1 activity of APOBEC3G in resting primary CD4 T cells," Journal of Virology, vol. 80, no. 15, pp. 7645-7657, 2006.

[21] A. Meier, G. Alter, N. Frahm, et al., "MyD88-dependent immune activation mediated by human immunodeficiency virus type 1-encoded Toll-like receptor ligands," Journal of Virology, vol. 81, no. 15, pp. 8180-8191, 2007.

[22] F. Demarchi, M. I. Gutierrez, and M. Giacca, "Human immunodeficiency virus type 1 Tat protein activates transcription factor NF- $\kappa \mathrm{B}$ through the cellular interferoninducible, double-stranded RNA-dependent protein kinase, PKR," Journal of Virology, vol. 73, no. 8, pp. 7080-7086, 1999.
[23] P. Roux, C. Alfieri, M. Hrimech, E. A. Cohen, and J. E. Tanner, "Activation of transcription factors NF- $\kappa$ B and NF-IL- 6 by human immunodeficiency virus type 1 protein $\mathrm{R}(\mathrm{Vpr})$ induces interleukin-8 expression," Journal of Virology, vol. 74, no. 10, pp. 4658-4665, 2000.

[24] S. Bour, C. Perrin, H. Akari, and K. Strebel, "The human immunodeficiency virus type $1 \mathrm{Vpu}$ protein inhibits NF- $\kappa \mathrm{B}$ activation by interfering with $\beta$ TrCP-mediated degradation of I $\kappa$ B," Journal of Biological Chemistry, vol. 276, no. 19, pp. 15920-15928, 2001.

[25] S. D. Tachado, J. Zhang, J. Zhu, N. Patel, and H. Koziel, "HIV impairs TNF- $\alpha$ release in response to Toll-like receptor 4 stimulation in human macrophages in vitro," American Journal of Respiratory Cell and Molecular Biology, vol. 33, no. 6, pp. 610-621, 2005.

[26] J. C. Bandres and L. Ratner, "Human immunodeficiency virus type 1 nef protein down-regulates transcription factors NF- $\kappa \mathrm{B}$ and AP-1 in human T cells in vitro after T-cell receptor stimulation," Journal of Virology, vol. 68, no. 5, pp. 3243-3249, 1994.

[27] A. Boasso, M. Vaccari, J. Nilsson, et al., "Do regulatory t-cells play a role in AIDS pathogenesis?" AIDS Reviews, vol. 8, no. 3, pp. 141-147, 2006.

[28] S. Chang, A. Dolganiuc, and G. Szabo, "Toll-like receptors 1 and 6 are involved in TLR2-mediated macrophage activation by hepatitis C virus core and NS3 proteins," Journal of Leukocyte Biology, vol. 82, no. 3, pp. 479-487, 2007.

[29] K. Li, E. Foy, J. C. Ferreon, et al., "Immune evasion by hepatitis $\mathrm{C}$ virus NS3/4A protease-mediated cleavage of the Toll-like receptor 3 adaptor protein TRIF," Proceedings of the National Academy of Sciences of the United States of America, vol. 102, no. 8, pp. 2992-2997, 2005.

[30] T. Abe, Y. Kaname, I. Hamamoto, et al., "Hepatitis C virus nonstructural protein $5 \mathrm{~A}$ modulates the Toll-like receptorMyD88-dependent signaling pathway in macrophage cell lines," Journal of Virology, vol. 81, no. 17, pp. 8953-8966, 2007.

[31] K.-J. Park, S.-H. Choi, D.-H. Choi, et al., "Hepatitis C virus NS5A protein modulates c-Jun N-terminal kinase through interaction with tumor necrosis factor receptor-associated factor 2," Journal of Biological Chemistry, vol. 278, no. 33, pp. 30711-30718, 2003.

[32] N. L. Yonkers, B. Rodriguez, K. A. Milkovich, et al., "TLR ligand-dependent activation of naive CD4 T cells by plasmacytoid dendritic cells is impaired in hepatitis C virus infection," Journal of Immunology, vol. 178, no. 7, pp. 4436-4444, 2007.

[33] L. Golden-Mason, B. Palmer, J. Klarquist, J. A. Mengshol, N. Castelblanco, and H. R. Rosen, "Upregulation of PD-1 expression on circulating and intrahepatic hepatitis $C$ virusspecific $\mathrm{CD}^{+} \mathrm{T}$ cells associated with reversible immune dysfunction," Journal of Virology, vol. 81, no. 17, pp. 9249-9258, 2007.

[34] M. Takeda, M. Tahara, T. Hashiguchi, et al., "A human lung carcinoma cell line supports efficient measles virus growth and syncytium formation via a SLAM- and CD46independent mechanism," Journal of Virology, vol. 81, no. 21, pp. 12091-12096, 2007.

[35] M. Takeda, "Measles virus breaks through epithelial cell barriers to achieve transmission," Journal of Clinical Investigation, vol. 118, no. 7, pp. 2386-2389, 2008.

[36] K. Bieback, E. Lien, I. M. Klagge, et al., "Hemagglutinin protein of wild-type measles virus activates Toll-like receptor 2 signaling," Journal of Virology, vol. 76, no. 17, pp. 8729-8736, 2002. 
[37] B. Hahm, J.-H. Cho, and M. B. A. Oldstone, "Measles virusdendritic cell interaction via SLAM inhibits innate immunity: selective signaling through TLR4 but not other TLRs mediates suppression of IL-12 synthesis," Virology, vol. 358, no. 2, pp. 251-257, 2007.

[38] L. de Witte, M. Abt, S. Schneider-Schaulies, Y. van Kooyk, and T. B. H. Geijtenbeek, "Measles virus targets DC-SIGN to enhance dendritic cell infection," Journal of Virology, vol. 80, no. 7, pp. 3477-3486, 2006.

[39] J. Schlender, V. Hornung, S. Finke, et al., "Inhibition of Toll-like receptor 7- and 9-mediated alpha/beta interferon production in human plasmacytoid dendritic cells by respiratory syncytial virus and measles virus," Journal of Virology, vol. 79, no. 9, pp. 5507-5515, 2005.

[40] C. Servet-Delprat, P.-O. Vidalain, H. Bausinger, et al., "Measles virus induces abnormal differentiation of CD40 ligandactivated human dendritic cells," Journal of Immunology, vol. 164, no. 4, pp. 1753-1760, 2000.

[41] T. Indoh, S. Yokota, T. Okabayashi, N. Yokosawa, and N. Fujii, "Suppression of NF- $\kappa \mathrm{B}$ and AP-1 activation in monocytic cells persistently infected with measles virus," Virology, vol. 361, no. 2, pp. 294-303, 2007.

[42] S. Yokota, T. Okabayashi, N. Yokosawa, and N. Fujii, "Measles virus $\mathrm{P}$ protein suppresses Toll-like receptor signal through up-regulation of ubiquitin-modifying enzyme A20," FASEB Journal, vol. 22, no. 1, pp. 74-83, 2008.

[43] A. Fernandez-Sesma, S. Marukian, B. J. Ebersole, et al., "Influenza virus evades innate and adaptive immunity via the NS1 protein," Journal of Virology, vol. 80, no. 13, pp. 6295-6304, 2006.

[44] B. G. Hale, R. E. Randall, J. Ortin, and D. Jackson, "The multifunctional NS1 protein of influenza A viruses," Journal of General Virology, vol. 89, part 10, pp. 2359-2376, 2008.

[45] J. A. Richt and A. Garcia-Sastre, "Attenuated influenza virus vaccines with modified NS1 proteins," Current Topics in Microbiology and Immunology, vol. 333, pp. 177-195, 2009.

[46] F. P. Polack, P. M. Irusta, S. J. Hoffman, et al., "The cysteinerich region of respiratory syncytial virus attachment protein inhibits innate immunity elicited by the virus and endotoxin," Proceedings of the National Academy of Sciences of the United States of America, vol. 102, no. 25, pp. 8996-9001, 2005.

[47] K. Reimers, K. Buchholz, and H. Werchau, "Respiratory syncytial virus M2-1 protein induces the activation of nuclear factor $\kappa$ B," Virology, vol. 331, no. 2, pp. 260-268, 2005.

[48] K. M. Spann, K. C. Tran, and P. L. Collins, "Effects of nonstructural proteins NS1 and NS2 of human respiratory syncytial virus on interferon regulatory factor $3, \mathrm{NF}-\kappa \mathrm{B}$, and proinflammatory cytokines," Journal of Virology, vol. 79, no. 9, pp. 5353-5362, 2005.

[49] J. Stack, I. R. Haga, M. Schroder, et al., "Vaccinia virus protein A46R targets multiple Toll-like-interleukin-1 receptor adaptors and contributes to virulence," Journal of Experimental Medicine, vol. 201, no. 6, pp. 1007-1018, 2005.

[50] G. Maloney, M. Schroder, and A. G. Bowie, "Vaccinia virus protein A52R activates p38 mitogen-activated protein kinase and potentiates lipopolysaccharide-induced interleukin10," Journal of Biological Chemistry, vol. 280, no. 35, pp. 30838-30844, 2005.

[51] G. DiPerna, J. Stack, A. G. Bowie, et al., "Poxvirus protein $\mathrm{N} 1 \mathrm{~L}$ targets the $\mathrm{I}-\kappa \mathrm{B}$ kinase complex, inhibits signaling to NF- $\kappa \mathrm{B}$ by the tumor necrosis factor superfamily of receptors, and inhibits NF- $\kappa \mathrm{B}$ and IRF3 signaling by Toll-like receptors," Journal of Biological Chemistry, vol. 279, no. 35, pp. 36570-36578, 2004.
[52] K. Slezak, K. Guzik, and H. Rokita, "Regulation of interleukin 12 and interleukin 10 expression in vaccinia virus-infected human monocytes and U-937 cell line," Cytokine, vol. 12, no. 7, pp. 900-908, 2000.

[53] Z. C. Hartman, E. P. Black, and A. Amalfitano, "Adenoviral infection induces a multi-faceted innate cellular immune response that is mediated by the Toll-like receptor pathway in A549 cells," Virology, vol. 358, no. 2, pp. 357-372, 2007.

[54] D. L. Lichtenstein, K. Toth, K. Doronin, A. E. Tollefson, and W. S. M. Wold, "Functions and mechanisms of action of the adenovirus E3 proteins," International Reviews of Immunology, vol. 23, no. 1-2, pp. 75-111, 2004.

[55] A. L. McNees, C. T. Garnett, and L. R. Gooding, "The adenovirus E3 RID complex protects some cultured human T and B lymphocytes from Fas-induced apoptosis," Journal of Virology, vol. 76, no. 19, pp. 9716-9723, 2002.

[56] F. Delgado-Lopez and M. S. Horwitz, "Adenovirus RID $\alpha \beta$ complex inhibits lipopolysaccharide signaling without altering TLR4 cell surface expression," Journal of Virology, vol. 80, no. 13, pp. 6378-6386, 2006.

[57] K. W. Boehme, M. Guerrero, and T. Compton, "Human cytomegalovirus envelope glycoproteins $\mathrm{B}$ and $\mathrm{H}$ are necessary for TLR2 activation in permissive cells," Journal of Immunology, vol. 177, no. 10, pp. 7094-7102, 2006.

[58] J. Vomaske, J. A. Nelson, and D. N. Streblow, "Human cytomegalovirus US28: a functionally selective chemokine binding receptor," Infectious Disorders-Drug Targets, vol. 9, no. 5, pp. 548-556, 2009.

[59] J. Eickhoff, M. Hanke, M. Stein-Gerlach, et al., "RICK activates a NF- $\kappa \mathrm{B}$-dependent anti-human cytomegalovirus response," Journal of Biological Chemistry, vol. 279, no. 10, pp. 9642-9652, 2004.

[60] M. A. Jarvis, J. A. Borton, A. M. Keech, et al., "Human cytomegalovirus attenuates interleukin-1 $\beta$ and tumor necrosis factor alpha proinflammatory signaling by inhibition of NF- $\kappa$ B activation," Journal of Virology, vol. 80, no. 11, pp. 5588-5598, 2006.

[61] C. Montag, J. Wagner, I. Gruska, and C. Hagemeier, "Human cytomegalovirus blocks tumor necrosis factor alpha- and interleulkin- $\beta$-mediated NF- $\kappa \mathrm{B}$ signaling," Journal of Virology, vol. 80, no. 23, pp. 11686-11698, 2006.

[62] E. Gaudreault, S. Fiola, M. Olivier, and J. Gosselin, "EpsteinBarr virus induces MCP-1 secretion by human monocytes via TLR2," Journal of Virology, vol. 81, no. 15, pp. 8016-8024, 2007.

[63] H. J. Martin, M. L. Jae, D. Walls, and S. D. Hayward, "Manipulation of the Toll-like receptor 7 signaling pathway by Epstein-Barr virus," Journal of Virology, vol. 81, no. 18, pp. 9748-9758, 2007.

[64] D. R. Averett, S. P. Fletcher, W. Li, S. E. Webber, and J. R. Appleman, "The pharmacology of endosomal TLR agonists in viral disease," Biochemical Society Transactions, vol. 35, no. 6, pp. 1468-1472, 2007.

[65] A. Makkouk and A. M. Abdelnoor, "The potential use of Tolllike receptor (TLR) agonists and antagonists as prophylactic and/or therapeutic agents," Immunopharmacology and Immunotoxicology, vol. 31, no. 3, pp. 331-338, 2009.

[66] M. P. Schon and M. Schon, "Imiquimod: mode of action," British Journal of Dermatology, vol. 157, supplement 2, pp. 8-13, 2007.

[67] D. Gregory, D. Hargett, D. Holmes, E. Money, and S. L. Bachenheimer, "Efficient replication by herpes simplex virus type 1 involves activation of the I $\kappa \mathrm{B}$ kinase-I $\kappa \mathrm{B}-\mathrm{p} 65$ pathway," Journal of Virology, vol. 78, no. 24, pp. 13582-13590, 2004. 
[68] M. T. Abreu, P. Vora, E. Faure, L. S. Thomas, E. T. Arnold, and M. Arditi, "Decreased expression of Toll-like receptor-4 and MD-2 correlates with intestinal epithelial cell protection against dysregulated proinflammatory gene expression in response to bacterial lipopolysaccharide," Journal of Immunology, vol. 167, no. 3, pp. 1609-1616, 2001.

[69] G. Melmed, L. S. Thomas, N. Lee, et al., "Human intestinal epithelial cells are broadly unresponsive to Toll-like receptor 2-dependent bacterial ligands: implications for host-microbial interactions in the gut," Journal of Immunology, vol. 170, no. 3, pp. 1406-1415, 2003.

[70] H. Kuwata, M. Matsumoto, K. Atarashi, et al., "I $\kappa$ BNS inhibits induction of a subset of Toll-like receptor-dependent genes and limits inflammation," Immunity, vol. 24, no. 1, pp. 41-51, 2006.

[71] S. Carpenter and L. A. J. O’Neill, "How important are Toll-like receptors for antimicrobial responses?" Cellular Microbiology, vol. 9, no. 8, pp. 1891-1901, 2007.

[72] E. A. Misch and T. R. Hawn, "Toll-like receptor polymorphisms and susceptibility to human disease," Clinical Science, vol. 114, no. 5-6, pp. 347-360, 2008. 


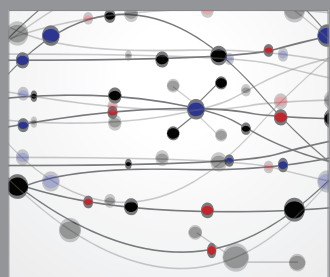

The Scientific World Journal
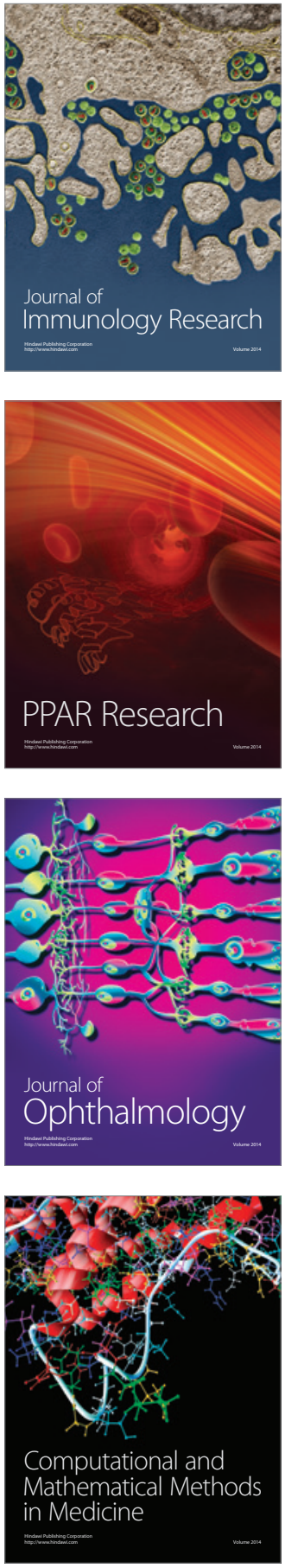

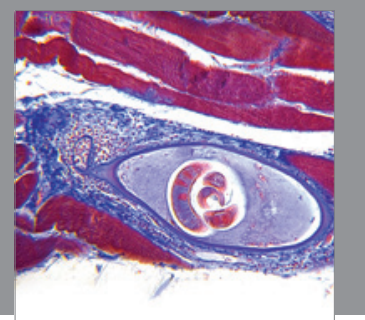

Gastroenterology

Research and Practice
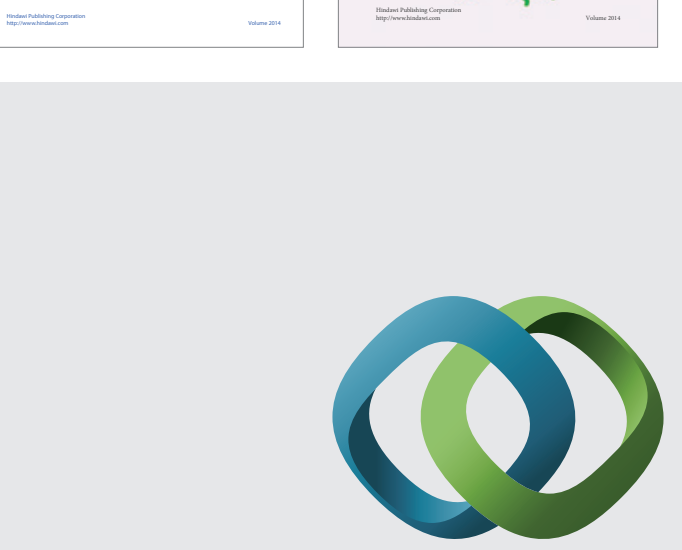

\section{Hindawi}

Submit your manuscripts at

http://www.hindawi.com
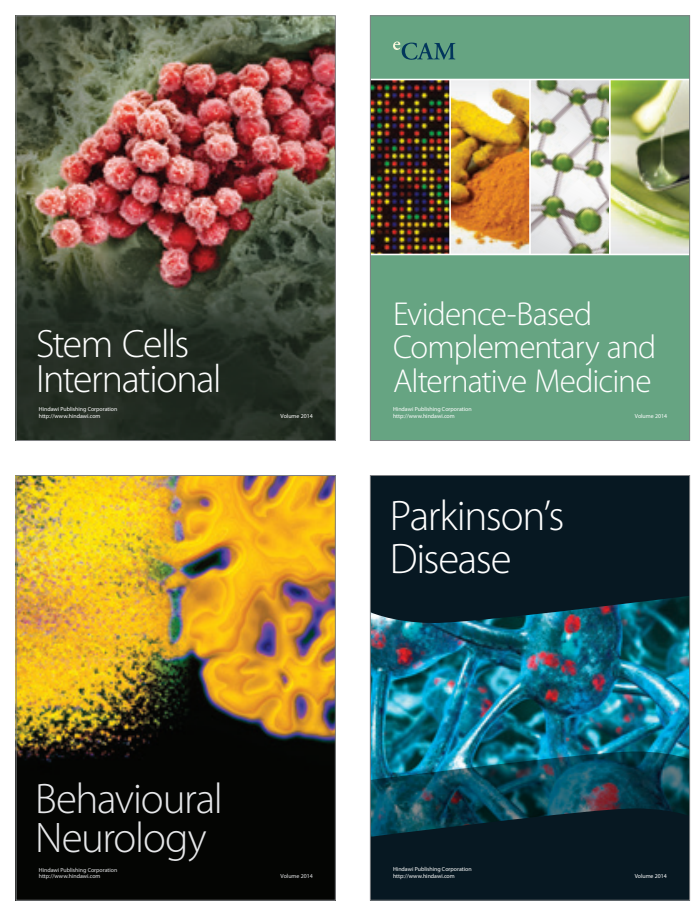

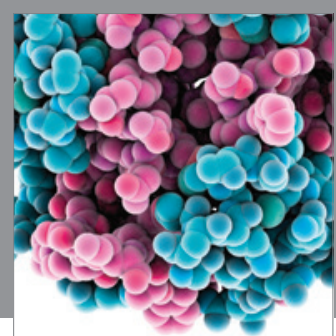

Journal of
Diabetes Research

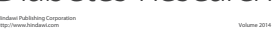

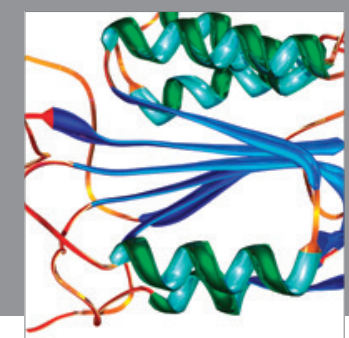

Disease Markers
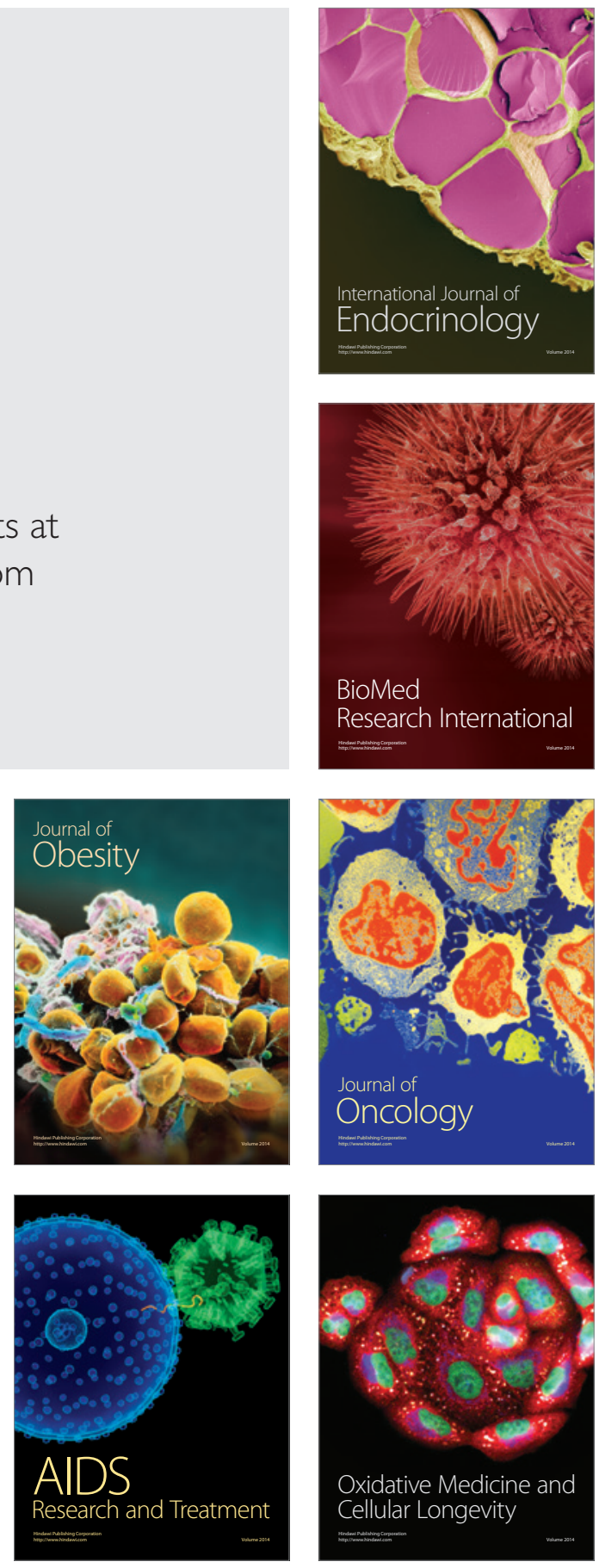